в регулировании вопросов в процессе рассмотрения дел административной юрисдикиии, представлены предложения по их устранению.

Ключевые слова: судебная экспертиза, административный процесс, участие эксперта в рассмотрении дел об административных правонарушениях, статус судебного эксперта.

\title{
LEGAL REGULATION OF FORENSIC EXAMINATION IN CASES ON ADMINISTRATIVE OFFENCES: CURRENT STATE AND DEVELOPMENT PROSPECTS
}

\begin{abstract}
Kliuiev $\boldsymbol{O}$. $M$.
One of the important means in establishing truth in the cases of administrative violations is forensic examination. As the court practice evidences, explanations of persons who take part in the case, often are contradictory, and only by scheduling and carrying out forensic examination, it is possible to establish validity of one or the other circumstances of the case reported by participants and which should be respectively evaluated by the court. The norms of the Code of Ukraine on Administrative Offences concerning of expert participation in the consideration of cases on administrative offenses are analyzed. The omissions in the regulation of issues during consideration of administrative jurisdiction cases, and presented proposals on directions of their elimination are identified. The sequence of carrying out expertise should be defined more clearly in the Code. In the first turn it is necessary to give a notion of forensic examination and to choose principles of forensic expert activity in the administrative process. Secondly, the Code should be added by types of forensic examination proceeding from choosing one criterion from a number of criteria on the basis of procedural indication. Thirdly, there exists a necessity to define more clearly requirements for a forensic expert. Fourthly, there is an objective need in more clear regulation of rights and obligations of a forensic expert. Besides, it is necessary to settle foundations and the order of expert participation in the consideration of cases on administrative offences. Thus the special attention needs to be turned on requirement for the decision of interests conflict questions, impossibility of the expert participation in the consideration of cases on administrative offences. Finally, there is a necessity to define forms and requirements for drawing up researches results in forensic expert conclusion.

Keywords: forensic examination, administrative process, expert participation in the consideration of cases on administrative offences, forensic expert status.
\end{abstract}

М. Г. Щербаковський, професор кафедри кримінально-правових дисциплін Харківського національного університету внутрішніх справ, доктор юридичних наук, доцент

\section{ОБОВ'ЯЗКОВЕ ПРИЗНАЧЕННЯ СУДОВИХ ЕКСПЕРТИЗ У КРИМІНАЛЬНОМУ ПРОВАДЖЕННІ}

Розглянуто проблему обов'язкового призначення судових експертиз згідно з вітчизняним і зарубіжним законодавством. Показано, щзо з урахуванням потреб практики та розвитку судових експертиз найбільш доціль-

(C) Щербаковский М. Г., 2016 
ним є формулювання процесуальної норми із загальними вимогами, які визначають випадки обов'язкового залучення експерта.

Ключові слова: судова експертиза, кримінальне провадження, обов 'язкове призначення, кримінально-процесуальний закон.

Висновок експерта є джерелом об'єктивної кримінально-релевантної інформації, що отримується на основі використання спеціальних знань. Проведення експертиз є засобом забезпечення об'єктивності, повноти та всебічності як досудового розслідування, так і судового провадження, гарантією захисту особи від необгрунтованого обвинувачення. Застосування спеціальних знань судових експертів у кримінальному провадженні становить невід'ємну й важливу частину як практичної діяльності із формування й оцінки доказів, так і її кримінально-процесуальної форми.

Однією із теоретичних та практичних проблем проведення судових експертиз $є$ обрання підстав обов'язковості їх призначення. Цьому питанню присвятили свої дослідження вітчизняні й зарубіжні вчені в галузі загальної теорії держави і права, кримінального, кримінально-процесуального права, криміналістики, судової експертизи та судової психіатрії, зокрема: В. Д. Арсеньєв, Р. С. Бєлкін, А. І. Вінберг, Л. Є. Владимиров, В. Г. Гончаренко, Г. І. Грамович, А. В. Дулов, В. Я. Дорохов, О. О. Ейсман, П. С. Елькінд, А. І. Слістратов, Ю. Г. Корухов, М. В. Костицький, В. К. Лисиченко, П. А. Лупінська, П. І. Люблінський, В. М. Махов, М. М. Міхеєнко, В. Т. Нор, Ю. К. Орлов, А. Я. Паліашвілі, М. Я. Сегай, М. С. Спасович, М. С. Строгович, І. Я. Фойницький, С. А. Шейфер, М. С. Шумило та ін. Як свідчить аналіз спеціальної літератури, вітчизняного та закордонного законодавств ця проблема далека від остаточного розв'язання. Правники в багатьох випадках лише констатують обов'язковість призначення експертиз із посиланням на відповідні статті Кримінального процесуального кодексу без розкриття критеріїв обов'язковості. Водночас указується й на те, що потреба в проведенні судових експертиз у кримінальних справах не вичерпується випадками, що вказані в законодавстві як обов'язкові для призначення. Тому зроблено висновок, що необхідність призначення експертиз у слідчій або судовій практиці найрізноманітніша, найбагатша та враховує особливості конкретної справи.

Метою статті $є$ визначення підстав обов'язкового призначення судових експертиз в Україні, країнах близького зарубіжжя та формулювання загального критерію, який визначав би випадки обов'язкового залучення експерта в кримінальному провадженні.

Відповідно до ст. 242 Кримінального процесуального кодексу України (далі - КПК) слідчий або прокурор призначають експертизу на свій розсуд, якщо в ній виникає необхідність, за винятком тих випадків, коли закон передбачає обов'язкове іiї призначення. У процесі доказування це означає, що обставини, перелічені в ч. 2 ст. 242 КПК, можуть бути встановлені тільки за допомогою такого джерела доказів, як висновок експерта. Законодавець увів категорію обов'язкових експертиз, без одержання результатів яких у певних випадках будь-яке кримінальне провадження як пізнавально-доказовий про- 
цес не може вважатися завершеним і виключає можливість прийняття підсумкового юридичного рішення. Обов'язкове призначення експертизи згідно з ч. 2 ст. 242 чинного КПК майже не відрізняється від КПК України 1960 р. та включає: 1) встановлення причин смерті; 2) встановлення тяжкості та характеру тілесних ушкоджень; 3) визначення психічного стану підозрюваного за наявності відомостей, які викликають сумнів щодо його осудності, обмеженої осудності; 4) встановлення віку особи, якщо це необхідно для вирішення питання про можливість притягнення ii до кримінальної відповідальності, а іншим способом неможливо отримати ці відомості; 5) встановлення статевої зрілості потерпілої особи в кримінальних провадженнях щодо злочинів, передбачених ст. 155 Кримінального кодексу України. 13 травня 2014 р. Законом України № 1261-VII уведений шостий пункт про обов'язкове призначення й проведення експертизи для «визначення розміру матеріальних збитків, шкоди немайнового характеру, шкоди довкіллю, заподіяної кримінальним правопорушенням». Це нововведення свідчить про розширення гарантій дотримання прав потерпілого, адже йдеться про збитки від учиненого злочину, які повинен компенсувати злочинець.

Перелік випадків обов'язкового призначення експертиз розширюють постанови Пленумів Верховного Суду України (далі - ВСУ). Відсутність у матеріалах кримінального провадження висновку експерта - одного 3 обов'язкових джерел доказів під час вирішення питання про винуватість або невинуватість особи дає підставу вважати, що слідство проведене односторонньо й необ'єктивне з порушенням кримінально-процесуального закону, а отже вирок підлягає скасуванню. Такі положення містяться в постановах пленумів ВСУ:

— «Про судову практику в справах про злочини у сфері обігу наркотичних засобів, психотропних речовин, їх аналогів або прекурсорів»: для встановлення виду, назви та властивостей наркотичного засобу, психотропної речовини, аналога такого засобу, речовини або прекурсора, їх походження, способу виготовлення чи переробки, а також належності наркотиковмісних рослин необхідні спеціальні знання, у кримінальних провадженнях даної категорії обов'язково має бути висновок експерта 3 цих питань ${ }^{1}$;

- «Про судову практику в справах про викрадення та інше незаконне поводження зі зброєю, бойовими припасами, вибуховими речовинами, вибуховими пристроями чи радіоактивними матеріалами»: для вирішення питання про те, чи є відповідні предмети зброєю, бойовими припасами, вибуховими речовинами, вибуховими пристроями або радіоактивними матеріалами необхідне обов'язково провадження експертизи ${ }^{2}$;

\footnotetext{
1 Див.: Про судову практику в справах про злочини у сфері обігу наркотичних засобів, психотропних речовин, їх аналогів або прекурсорів : постанова Пленуму ВСУ від 26.04.2002 № 4 (із змінами, унесеними згідно з постановою Пленуму ВСУ від 18.12.2009 № 16, п. 2) [Електронний ресурс]. — Режим доступу : http://zakon3. rada.gov.ua/laws/show/v0004700-02.

2 Див.: Про судову практику в справах про викрадення та інше незаконне поводження зі зброєю, бойовими припасами, вибуховими речовинами, вибуховими пристроями чи радіоактивними матеріалами : постанова Пленуму ВСУ від 26.04.2002
} 
— «Про практику застосування судами України законодавства у справах про злочини неповнолітніх»: за наявності даних, що свідчать про розумову відсталість неповнолітнього, має бути призначена судова психолого-психіатрична експертиза для вирішення питання про наявність чи відсутність у неповнолітнього відставання в психічному розвитку, про ступінь такого відставання, установлення стану його загального розвитку з метою з'ясування питання про те, чи міг неповнолітній повністю усвідомлювати значення своїх дій і якою мірою міг керувати ними ${ }^{1}$;

— «Про практику застосування судами України законодавства у справах про злочини проти безпеки виробництва»: у випадках, коли для вирішення певних питань під час кримінального провадження необхідні наукові, технічні або інші спеціальні знання, суд має призначити експертизу루

— «Про судову практику в справах про злочини проти життя та здоров'я особи»: для встановлення причин смерті, тяжкості й характеру тілесних ушкоджень призначення експертизи є обов'язковим. Для з'ясування, чи вчинено діяння в стані сильного душевного хвилювання, суд має призначати психолого-психіатричну експертизуз;

- «Про судову практику у справах про злочини проти власності»: розмір майна, яким заволоділа винна особа в результаті вчинення злочину, визначається за роздрібними (закупівельними) цінами, що існували на момент учинення злочину, а розмір відшкодування завданих злочином збитків - за відповідними цінами на час вирішення справи в суді. За відсутності зазначених цін на майно його вартість може бути визначено шляхом проведення відповідної експертизи

— «Про судову практику у справах про злочини проти статевої свободи та статевої недоторканості особи»: для визначення характеру впливу на організм потерпілої особи лікарських препаратів, наркотичних засобів, отруйних, токсичних чи інших сильнодіючих речовин, уживання яких могло призвести ії до безпорадного стану, слід призначати відповідну експертизу5;

№ 3, п. 10 [Електронний ресурс]. — Режим доступу : http://zakon3.rada.gov.ua/laws/ show/v0003700-02.

${ }^{1}$ Див.: Про практику застосування судами України законодавства у справах про злочини неповнолітніх : постанова Пленуму ВСУ від 16.04.2004 № 5, П. 7 [Електронний ресурс]. - Режим доступу : http://zakon3.rada.gov.ua/laws/show/va005700-04.

${ }_{2}$ Див.: Про практику застосування судами України законодавства у справах про злочини проти безпеки виробництва : постанова Пленуму ВСУ від 12.06.2009 № 7, п. 3 [Електронний ресурс]. — Режим доступу : http://zakon4.rada.gov.ua/laws/show/ va007700-09.

3 Див.: Про судову практику в справах про злочини проти життя та здоров'я особи : постанова Пленуму ВСУ від 7.02.2003 № 2, п. 27 [Електронний ресурс]. Режим доступу : http://zakon4.rada.gov.ua/laws/show/v0002700-03.

${ }^{4}$ Див.: Про судову практику у справах про злочини проти власності : постанова Пленуму ВСУ від 06.11.2009 № 10, п. 25 [Електронний ресурс]. — Режим доступу : http://zakon4.rada.gov.ua/laws/show/v0010700-09.

5 Див.: Про судову практику у справах про злочини проти статевої свободи та статевої недоторканості особи : постанова Пленуму ВСУ від 30.05.2008 № 5, п. 5 [Електронний ресурс]. - Режим доступу : http://zakon3.rada.gov.ua/laws/show/v0005700-08. 
— «Про практику розгляду судами кримінальних справ про виготовлення або збут підроблених грошей чи цінних паперів»: питання про те, чи $\epsilon$ грошові знаки або державні цінні папери підробленими, який спосіб підробки при цьому використовувався, чи не були раніше грошові знаки або державні цінні папери з аналогічними ознаками підробки предметом криміналістичного дослідження тощо, повинні вирішуватися за допомогою криміналістичної експертизи ${ }^{1}$;

— «Про практику застосування судами України законодавства у справах про деякі злочини проти безпеки дорожнього руху та експлуатації транспорту, а також про адміністративні правопорушення на транспорті»: коли для вирішення питань, які виникли в справі про злочин проти безпеки дорожнього руху або експлуатації транспорту, потрібні спеціальні знання, суд має призначити експертизу².

По-різному питання обов'язкового призначення експертизи вирішується в країнах близького зарубіжжя. Із 14 колишніх радянських республік (за винятком України) у КПК Грузії, Литви й Естонії взагалі не передбачені такі ситуації. В інших країнах норма про обов'язкове призначення експертизи в КПК існує. Серед обставин, що встановлюються виключно експертизою, у всіх КПК указані причина смерті, ступінь тяжкості тілесних ушкоджень (шкода здоров’ю), вік підозрюваного, його психічний стан. Проте інші підстави обов'язкового проведення експертизи відрізняються від ст. 242 КПК України. Ними визначені:

- можливість правильного сприйняття й опису свідком обставин, що підлягають установленню в кримінальній справі (статті 264.2, 140.0.1-140.0.4 КПК Азербайджанської Республіки, ст. 108 КПК Республіки Вірменія, ст. 271 КПК Республіки Казахстан, ст. 200 КПК Киргизької Республіки, ст. 195 КПК Латвійської Республіки, ст. 143 КПК Республіки Молдова, ст. 209 КПК Республіки Таджикистан, ст. 288 КПК Республіки Туркменистан, ст. 173 КПК Республіки Узбекистан);

- можливість правильного сприйняття й опису потерпілим обставин, що підлягають установленню в кримінальній справі (статті 264.2, 140.0.1140.0.4 КПК Азербайджанської Республіки, ст. 108 КПК Республіки Вірменія, ст. 228 КПК Республіки Білорусь, ст. 271 КПК Республіки Казахстан, ст. 200 КПК Киргизької Республіки, ст. 195 КПК Латвійської Республіки, ст. 143 КПК Республіки Молдова, ст. 196 КПК Російської Федерації, ст. 209 КПК Республіки Таджикистан, ст. 288 КПК Республіки Туркменистан, ст. 173 КПК Республіки Узбекистан);

1 Див.: Про практику розгляду судами кримінальних справ про виготовлення або збут підроблених грошей чи цінних паперів : постанова Пленуму ВСУ від 12.04.1996 № 6, п. 6 [Електронний ресурс]. — Режим доступу : http://zakon3.rada.gov. ua/laws/show/v0006700-96.

2 Див.: Про практику застосування судами України законодавства у справах про деякі злочини проти безпеки дорожнього руху та експлуатації транспорту, а також про адміністративні правопорушення на транспорті : постанова Пленуму ВСУ від 23.12.2005 № 14 (із змінами, унесеними згідно з постановою Пленуму ВСУ від 19.12.2008 № 18, п. 19) [Електронний ресурс]. — Режим доступу : http://zakon3.rada. gov.ua/laws/show/v0014700-05. 
— вік потерпілого (статті 264.2, 140.0.1-140.0.4 КПК Азербайджанської Республіки, ст. 108 КПК Республіки Вірменія, ст. 228 КПК Республіки Білорусь, ст. 271 КПК Республіки Казахстан, ст. 200 КПК Киргизької Республіки, ст. 195 КПК Латвійської Республіки, ст. 143 КПК Республіки Молдова, ст. 196 КПК Російської Федерації, ст. 209 КПК Республіки Таджикистан, ст. 288 КПК Республіки Туркменистан, ст. 173 КПК Республіки Узбекистан);

- фізичний стан підозрюваного, обвинувачуваного, коли виникає сумнів із приводу спроможності самостійно захищати свої права й законні інтереси в кримінальному процесі (ст. 228 КПК Республіки Білорусь, ст. 271 Республіки Казахстан, ст. 143 КПК Республіки Молдова, ст. 196 КПК Російської Федерації, ст. 209 КПК Республіки Таджикистан, ст. 288 КПК Республіки Туркменистан, ст. 173 КПК Республіки Узбекистан);

- психічний і фізичний стан особи, відносно якої можливо застосовувалися катування, нелюдське або принижуюче людську гідність поводження (ст. 143 КПК Республіки Молдова);

— вагітність або факт її штучного переривання (ст. 195 КПК Латвійської Республіки, ст. 173 КПК Республіки Узбекистан);

- факт вступу в статевий зв'язок (ст. 195 КПК Латвійської Республіки, ст. 173 КПК Республіки Узбекистан);

- справжність грошей і цінних паперів; установлення наркотичних речовин, психотропних речовин і прекурсорів (ст. 195 КПК Латвійської Республіки, ст. 173 КПК Республіки Узбекистан);

- ідентичність померлої особи, якщо проведена ексгумація трупа; установлення зброї, боєприпасів або вибухових речовин (ст. 195 КПК Латвійської Республіки);

- психічний стан підозрюваного, обвинуваченого у віці старше вісімнадцяти років під час розслідування злочину проти статевої недоторканості неповнолітнього, який не досяг чотирнадцяти років, для вирішення питання про наявність або відсутність у нього розладу сексуальної переваги (педофілії) (ст. 196 КПК Російської Федерації);

- психічний або фізичний стан підозрюваного, обвинуваченого, коли $є$ підстави вважати, що він є хворим на наркоманію (ст. 196 КПК Російської Федерації);

- необхідність і можливість лікування осіб, що страждають венеричними й іншими інфекційними захворюваннями, хронічним алкоголізмом і наркоманісю (ст. 173 КПК Республіки Узбекистан);

- технічні причини вибухів, катастроф та інших надзвичайних подій (ст. 173 КПК Республіки Узбекистан).

Цікаво відзначити, що в КПК Азербайджанської Республіки, Республіки Вірменія, Республіки Білорусь, Киргизької Республіки, Латвійської Республіки, Російської Федерації, Республіки Таджикистан, Республіки Туркменистан наведений вичерпний перелік таких ситуацій, а в КПК Республіки Казахстан, Республіки Молдова, Республіки Узбекистан, крім перерахованих випадків, зазначено, що призначення й проведення експертизи обов'язкові, якщо в кримінальному провадженні необхідно встановити інші обставини, 
які не можуть бути достовірно визначені іншими доказами. Аналіз обов'язкових випадків проведення експертизи, перерахованих у КПК різних країн, а також рекомендаціях ВСУ, показує, що вони спрямовані на встановлення ознак, предмета, суб'єкта, суб'єктивної сторони злочину, слугують підставою кваліфікації злочинної дії та оцінки інших доказів.

Виникає запитання: чи можливо в одній нормі об'єднати всі випадки обов'язкового проведення експертизи? Р. С. Бєлкін пропонує три варіанти вирішення цієї проблеми: 1) розширити перелік випадків обов'язкового призначення судової експертизи; 2) сформулювати в КПК правову норму, у якій була б виражена загальна вимога, загальні умови обов'язкового призначення експертизи замість детального переліку таких випадків, маючи на увазі, що практика вносить корективи в будь-який такий перелік; 3) сконструювати в КПК таку норму, яка у своєму змісті об'єднала б перший і другий підходи: містила б перелік найпоширеніших випадків обов'язкового застосування експертизи, а також формулу, що дозволяла б розширювати цей перелік залежно від обставин кримінального провадження і його характеру ${ }^{1}$.

Більшість пропозицій, наведених у літературі, стосується першого напряму. Так, Б. М. Бішманов пропонує обов'язково призначати експертизу для встановлення психічного або фізичного стану особи, яка вчинила злочин, за який передбачена смертна кара ${ }^{2}$. С. В. Міщенко вважає обов'язковим проведення судово-психіатричної експертизи перед прийняттям рішення про застосування примусових заходів медичного характеру․․ В. В. Курдюков пропонує обов'язково призначати судово-психологічну експертизу у випадках, коли: а) виникають обгрунтовані сумніви в можливості людини (у тому числі й неповнолітнього) повністю усвідомлювати значення своїх дій, керувати ними та передбачати наслідки таких дій; б) є підстави вважати, що людина за своїм психічним розвитком не досягла рівня віку, з якого може настати кримінальна відповідальність, хоча їі біологічний вік передбачає таку можливість; в) характер дій людини та їі стан після їх учинення свідчать про наявність у неї фізіологічного афекту 4 . На думку О. М. Бандурки зі співавторами, слід уважати обов'язковим проведення судово-психологічної експертизи, якщо стосовно психічно здорових свідків чи потерпілих виникає сумнів у їх здатності через індивідуально-психологічні або вікові особливості правильно сприймати

\footnotetext{
1 Див.: Белкин Р. С. Курс криминалистики : пособие / Р. С. Белкин. - М.: ЮНИТИ-ДАНА, Закон и право, 2001. - С. 620.

2 Див.: Бишманов Б. М. Производство судебной экспертизы в уголовном процессе / Б. М. Бишманов // Вест. Оренбург. гос. ун-та. — 2004. — № 3. - С. 68.

3 Див.: Мищенко E. В. Обязательное производство судебно-психиатрической экспертизы по делам о применении принудительной меры медицинского характера / Е. В. Мищенко // Вест. Оренбург. гос. ун-та. — 2007. — № 3. - С. 33.

${ }^{4}$ Див.: Курдюков В. В. Теоретичні засади та критерії обов'язкового призначення судових експертиз в кримінальному процесі України : автореф. дис. на здобуття наук. ступеня канд. юрид. наук : спец. 12.00 .09 «Кримінальний процес та криміналістика; судова експертиза» / В. В. Курдюков. - К., 2009. - С. 14.
} 
обставини, що мають значення для справи, і давати про них правильні показання ${ }^{1}$. Н. С. Карпов також уважає за доцільне доповнити ч. 2 ст. 242 КПК України положенням, що слідчий, прокурор зобов' язані призначити експертизу, коли виникає сумнів про те, чи може свідок або потерпілий у силу своїх фізичних чи психічних недоліків правильно сприймати факти, які мають доказове значення, і давати показання про них ${ }^{2}$. О. В. Константинов пропонує доповнити підстави обов'язкового призначення судової експертизи випадками, коли спеціаліст укаже на необхідність призначення експертизи, або коли сторони після ознайомлення $з$ поясненнями спеціаліста заявили клопотання про потребу призначення експертизи ${ }^{3}$. Ця пропозиція викликає сумнів, оскільки об'єктивні чинники обов'язкового призначення експертиз підмінюються суб'єктивною думкою навіть обізнаної особи.

Проблема обов'язкового призначення експертиз вирішується законодавцями більшості держав шляхом переліку таких випадків та їх розширення в міру необхідності. Прикладом може слугувати зазначене доповнення, унесене до ст. 242 КПК України через три роки після його прийняття. Однак розвиток судової експертизи, розширення можливостей встановлення різних обставин злочину неминуче приведе до необхідності розширення переліку випадків обов'язкового призначення експертиз. Такі ситуації, відповідаючи потребам практики сьогодення, не будуть мати необхідного запасу міцності: залежно від зміни характеру злочинності й появи нових видів злочинів, розширення можливостей експертиз щодо розширення кола завдань, які стають доступними для вирішення за найрізноманітнішими категоріями кримінальних проваджень. Тому перелік ситуацій обов'язкового призначення експертиз буде безсумнівно розширюватися слідчою практикою й вимогами суду. По суті в майбутньому виникне ситуація сьогоднішнього дня, але вже стосовно нового, розширеного законодавцем переліку.

А. В. Кудрявцева $є$ прихильником формулювання норми, що передбачає загальні критерії обов'язкового призначення й проведення експертизи. У цій нормі вона пропонує вказати, що експертиза є обов'язковою, якщо «для встановлення істотних для кримінального провадження обставин необхідне проведення глибоких досліджень на основі спеціальних знань у галузі науки, техніки, мистецтва або ремесла, а також для встанов-

${ }^{1}$ Див.: Бандурка А. М. Юридическая психология : учебник / А. М. Бандурка, С. П. Бочарова, Е. В. Землянская. - Харьков: Нац. ун-т внутр. дел, 2002. C. 295.

2 Див.: Карпов Н. С. Использование специальных знаний по уголовно-процессуальному законодательству Украины / Н. С. Карпов // Известия Тул. гос. ун-та. Эконом. и юрид. науки. - Тула, 2013. - № 4-2. - С. 76.

3 Див.: Константинов A. B. Процессуальные и организационные проблемы участия специалиста в уголовном судопроизводстве на стадии предварительного расследования : автореф. дис. на соискание уч. степени канд. юрид. наук : спец. 12.00 .09 «Уголовный процесс, криминалистика и судебная экспертиза, оперативнорозыскная деятельность» / А. В. Константинов. - М., 2006. - С. 10. 
лення кримінально-процесуальної дієздатності учасників кримінального судочинства» ${ }^{1}$. Погоджуючись у цілому з цією пропозицією, не можна не зробити два заперечення. По-перше, незрозуміло, що таке «істотні» обставини. По-друге, викликає зауваження вказівка на необхідність проведення «глибоких досліджень». «Глибина» або складність досліджень поняття оцінне, яке залежить від багатьох факторів, починаючи від поставленого завдання, кількості і якості об’єктів, наявності методики дослідження та ін. Наприклад, чи слід вважати встановлення належності ножа до кримінально-правової категорії «холодна зброя» глибоким дослідженням, коли проводяться: 1) огляд предмета для зіставлення подібності його зовнішньої будови (форми конструкції в цілому та форми окремих характерних конструктивних елементів) з відомими аналогами-зразками холодної зброї; установлення комплексу конструктивних елементів, що дозволяють віднести його до певного виду й типу холодної зброї; 2) вимірювання розмірів окремих елементів, установлення характеристик міцності як конструкції в цілому, так і окремих деталей ${ }^{2}$. Узагалі це дослідження не можна вважати складним, але воно обов'язкове для кваліфікації діяння.

Ми підтримуємо пропозицію про формулювання загальної норми про обов'язкове залучення експерта (призначення експертизи). На нашу думку, має рацію В. В. Курдюков, стверджуючи про необхідність визначення єдиного критерію обов'язковості призначення експертиз. За критерій автор узяв людину та їі життєдіяльність ${ }^{3}$. Водночас цей критерій не узгоджується із наведеними численними різноманітними ситуаціями обов'язкового залучення експертів під час розслідування злочинів, не пов'язаних із дослідженням людини. Уважаємо, що таким загальним критерієм повинна стати неможливість отримання доказів у кримінальному провадженні будь-якими засобами доказування, як тільки використанням спеціальних знань у формі судової експертизи. На наш погляд, застосування цього критерію обов'язкового призначення експертизи дасть можливість усебічно та повно дослідити обставини вчиненого кримінального правопорушення і є підставою винесення об’єктивного судового рішення.

Таким чином, пропонуємо таке формулювання ч. 2 ст. 242 КПК України: «Сторони кримінального провадження обов'язково залучають експерта, а слідчий суддя або суд доручають проведення експертизи експертній установі, експерту або експертам, якщо відомості про обставини, які мають значення для кримінального провадження, можливо встановити тільки шляхом проведення експертизи».

${ }^{1}$ Кудрявцеева A. B. Дискуссионные вопросы назначения и проведения экспертиз в уголовном процессе России / А. В. Кудрявцева // Вестник Южно-Урал. гос. ун-та. Серия «Право». - 2007. - Вып. 9. - № 4. - С. 84.

2 Див.: Методика криміналістичного дослідження холодної зброї та конструктивно схожих 3 нею виробів : рішення розширеного засідання секції НКМР Міністерства юстиції України з проблем трасології та судової балістики із залученням членів Координаційної ради 3 питань судової експертизи [Електронний ресурс] // Протокол від 15.01.1999 (із змінами від 12.09.2014). — Режим доступу : http://zakon4. rada.gov.ua/laws/show/n0002320-99.

3 Див.: Курдюков В. В. Указ. праця. - С. 10, 13. 


\title{
ОБЯЗАТЕЛЬНОЕ НАЗНАЧЕНИЕ СУДЕБНЫХ ЭКСПЕРТИЗ В УГОЛОВНОМ ПРОИЗВОДСТВЕ
}

\author{
Щербаковский М. Г.
}

Рассмотрена проблема обязательного назначения судебных экспертиз согласно отечественному и зарубежному законодательству. Показано, что с учетом потребностей практики и развития судебных экспертиз наиболее ичелесообразным является формулирование процессуальной нормы с общчими требованиями, определяющими случаи обязательного привлечения эксперта.

Ключевые слова: судебная экспертиза, уголовное производство, обязательное назначение, уголовно-прочессуальный закон.

\section{ON COMPULSORY ORDERING FORENSIC EXAMINATIONS IN CRIMINAL PROCEEDINGS}

\section{Scherbakovskiy M. G.}

The paper discusses problem of compulsory use of forensic examinations in the inquiry process of crimes. Criminal procedural laws of Azerbaijan, Armenia, Belarus, Georgia, Kazakhstan, Kyrgyzstan, Latvia, Lithuania, Moldova, Russia, Tajikistan, Turkmenistan, Uzbekistan, Ukraine and Estonia are considered. The needs of the investigative and judicial practice, modern possibilities of forensic examinations on research of various objects and on the establishment of the committed crimes circumstances are analyzed. The author believes that the Code of Criminal Procedure should not contain an exhaustive list of cases of compulsory involvement of a forensic expert. In article 242 of the Criminal Procedural Code of Ukraine there are only six cases of compulsory scheduling forensic examinations, five of which are already well-known, and the sixth has been introduced in 2014 in order to determine the amount of material damage, non-material damage, damage to the environment caused by a criminal offense. However, the actual number of such cases is substantially more. These cases are listed in the Decisions of Plenums of the Supreme Court of Ukraine which summarize the judicial practice on the crimes: in the field of illicit drug trafficking; about the theft and illegal dealing with weapons, ammunition, radioactive substances; committed by minors; against safety of the production; against life and health; against property; against sexual freedom and sexual inviolability of a personality; on the manufacture and sale of counterfeit money or securities; against road traffic safety and transport operation. The author formulates the general criterion which outlines the conditions of the compulsory use of forensic examinations. Such a criterion is the possibility of obtaining evidence in criminal proceedings only as a result of use of special knowledge in the form of forensic examination.

Keywords: forensic examination, criminal proceedings, compulsory ordering, criminal procedural law. 